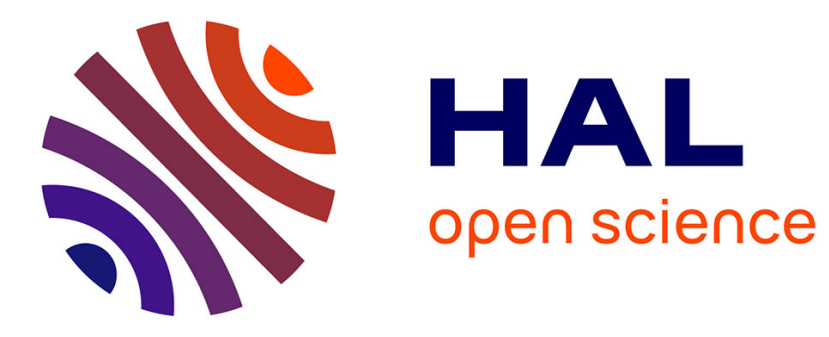

\title{
Is Static Hyperinflation a Limiting Factor during Exercise in Adolescents with Cystic Fibrosis?
}

Maarten Werkman, Erik Hulzebos, Bert Arets, Janjaap van Der Net, Paul Helders, Tim Takken

\section{- To cite this version:}

Maarten Werkman, Erik Hulzebos, Bert Arets, Janjaap van Der Net, Paul Helders, et al.. Is Static Hyperinflation a Limiting Factor during Exercise in Adolescents with Cystic Fibrosis?. Pediatric Pulmonology, 2010, 46 (2), pp.119. 10.1002/ppul.21329 . hal-00599811

\section{HAL Id: hal-00599811 https://hal.science/hal-00599811}

Submitted on 11 Jun 2011

HAL is a multi-disciplinary open access archive for the deposit and dissemination of scientific research documents, whether they are published or not. The documents may come from teaching and research institutions in France or abroad, or from public or private research centers.
L'archive ouverte pluridisciplinaire HAL, est destinée au dépôt et à la diffusion de documents scientifiques de niveau recherche, publiés ou non, émanant des établissements d'enseignement et de recherche français ou étrangers, des laboratoires publics ou privés. 


\section{Is Static Hyperinflation a Limiting Factor during Exercise in Adolescents with Cystic Fibrosis?}

\begin{tabular}{|r|l|}
\hline Journal: & Pediatric Pulmonology \\
\hline Manuscript ID: & PPUL-09-0441.R2 \\
\hline Wiley - Manuscript type: & Original Article \\
\hline Date Submitted by the & 09-Jun-2010 \\
\hline Complete List of Authors: & $\begin{array}{l}\text { Werkman, Maarten; University Children's Hospital and Medical } \\
\text { Center Utrecht, Child Development and Exercise Center } \\
\text { Hulzebos, Erik; University Children's Hospital and Medical Center } \\
\text { Utrecht, Child Development and Exercise Center } \\
\text { Arets, Bert; University Medical Center Utrecht, Pediatric Respiratory } \\
\text { Medicine } \\
\text { van der Net, Janjaap; University Children's Hospital and Medical } \\
\text { Center Utrecht, Child Development and Exercise Center } \\
\text { Helders, Paul; University Children's Hospital and Medical Center } \\
\text { Utrecht, Child Development and Exercise Center } \\
\text { Takken, Tim; University Children's Hospital and Medical Center } \\
\text { Utrecht, Child Development and Exercise Center }\end{array}$ \\
\hline Keywords: & $\begin{array}{l}\text { work of breathing, ventilatory limitation, cardiopulmonary exercise } \\
\text { testing }\end{array}$ \\
\hline
\end{tabular}

\section{scholaroNE" Manuscript Central}


Is static hyperinflation a limiting factor during exercise in CF?

IS STATIC HYPERINFLATION A LIMITING FACTOR DURING EXERCISE IN ADOLESCENTS WITH CYSTIC FIBROSIS?

\author{
M.S. Werkman, MSc, $\mathrm{PT}^{1}$, H.J. Hulzebos, PhD, MSc, $\mathrm{PT}^{1}$, H.G.M. Arets, MD, $\mathrm{PhD}^{2}$, J. van \\ der Net, PhD, PT, PCS ${ }^{1}$, P.J.M. Helders, PhD, MSc, PT, PCS ${ }^{1}$, T. Takken, PhD, $\mathrm{MSc}^{1}$ \\ ${ }^{1}$ Child Development \& Exercise Center and ${ }^{2}$ Department of Pediatric Respiratory Medicine, \\ Cystic Fibrosis Center, University Medical Center Utrecht, Utrecht, the Netherlands
}

Corresponding author:

Hulzebos H.J.,

Child Development \& Exercise Center

University Medical Center Utrecht

P.O. Box 85090

3508 AB Utrecht

The Netherlands.

Phone +318875 $54030 /$ Fax +31088 7555333

E-mail: $\underline{\text { H.Hulzebos@umcutrecht.nl }}$

Running title: Is static hyperinflation a limiting factor during exercise in CF? 
Is static hyperinflation a limiting factor during exercise in CF?

\begin{abstract}
Summary
Increased work of breathing is considered to be a limiting factor in patients with Cystic Fibrosis (CF) during exercise. We hypothesized that adolescents with CF and with static hyperinflation are more prone to a ventilatorily limited exercise capacity than non-static hyperinflated adolescents with CF.

Exercise data of 119 adolescents with CF [range 12-18 yrs.], stratified for static hyperinflation, defined as ratio of residual volume to total lung capacity (RV/TLC) $>30 \%$, were obtained during a progressive bicycle ergometer test with gas analysis and analyzed for ventilatory limitation.
\end{abstract}

Static hyperinflation showed a significant, though weak association $(\Phi 0.38 ; \mathrm{p}<.001)$ with a ventilatorily limited exercise capacity (Breathing Reserve Index at maximal effort $>0.70$; $\mathrm{FEV}_{1}<80 \%$ predicted and reduced exercise capacity, defined as $\mathrm{VO}_{2 \text { peak }}<85 \%$ predicted). Analysis of association for increasing degrees of hyperinflation showed an increase to $\Phi .49$ $(\mathrm{p}<.001)$ for RV/TLC $>50 \%$. In adolescents with static hyperinflation, peak work rate $\left(\mathrm{W}_{\text {peak }} ; 3.1 \pm 0.7 \mathrm{Watt} / \mathrm{kg}(75.1 \pm 17.3 \%\right.$ of predicted $)$, peak oxygen uptake $\left(\mathrm{VO}_{2 \text { peak }} / \mathrm{kg}\right.$ $(\mathrm{ml} / \mathrm{min} / \mathrm{kg}) ; 39.2 \pm 9.2 \mathrm{ml} / \mathrm{min} / \mathrm{kg}(91.0 \pm 20.3 \%$ of predicted $)$, peak heart rate $\left(\mathrm{HR}_{\text {peak }} ; 176 \pm 19\right.$ beats/min) were significantly $(\mathrm{p}<.05)$ decreased when compared with non-static hyperinflated adolescents $\left(\mathrm{W}_{\text {peak }} 3.5 \pm 0.5 \mathrm{Watt} / \mathrm{kg}(81.4 \pm 10.0 \%\right.$ of predicted $\left.)\right) ; \mathrm{VO}_{2 \text { peak }} / \mathrm{kg}$ $(\mathrm{ml} / \mathrm{min} / \mathrm{kg}) ; 43.1 \pm 7.5 \mathrm{ml} / \mathrm{min} / \mathrm{kg}(98.0 \pm 15.1 \%$ of predicted $)$ and $\mathrm{HR}_{\text {peak }} 185 \pm 14$ beats $\left./ \mathrm{min}\right)$. Additionally, no difference was found in the degree of association of $\mathrm{FEV}_{1}(\%)$ and RV/TLC (\%) with $\mathrm{VO}_{2 \text { peak }} / \mathrm{kg}_{\text {pred }}$ and $\mathrm{W}_{\text {peak }} / \mathrm{kg}_{\text {Pred }}$, but we found the $\mathrm{RV} / \mathrm{TLC}(\%)$ to be a slightly stronger predictor of $\mathrm{VO}_{2 \text { peak }} / \mathrm{kg}_{\text {pred }}$ and $\mathrm{W}_{\text {peak }} / \mathrm{kg}_{\text {Pred }}$ than $\mathrm{FEV}_{1}(\%)$.

These results indicate that the presence of static hyperinflation in adolescents with CF by itself does not strongly influence ventilatory constraints during exercise and that static 
Is static hyperinflation a limiting factor during exercise in CF?

hyperinflation is only a slightly stronger predictor of $\mathrm{W}_{\text {peak }} / \mathrm{kg}_{\text {Pred }}$ and $\mathrm{VO}_{2 \text { peak }} / \mathrm{kg}_{\text {Pred }}$ than airflow obstruction $\left(\mathrm{FEV}_{1}(\%)\right)$.

Keywords: work of breathing; ventilatory limitation; cardiopulmonary exercise testing 
Is static hyperinflation a limiting factor during exercise in CF?

\title{
IS STATIC HYPERINFLATION A LIMITING FACTOR DURING EXERCISE IN ADOLESCENTS WITH CYSTIC FIBROSIS?
}

\author{
M.S. Werkman, MSc, $\mathrm{PT}^{1}$, H.J. Hulzebos, PhD, MSc, PT ${ }^{1}$, H.G.M. Arets, MD, $\mathrm{PhD}^{2}$, J. van \\ der Net, PhD, PT, PCS ${ }^{1}$, P.J.M. Helders, PhD, MSc, PT, PCS ${ }^{1}$, T. Takken, PhD, $\mathrm{MSc}^{1}$ \\ ${ }^{1}$ Child Development \& Exercise Center and ${ }^{2}$ Department of Pediatric Respiratory Medicine, \\ Cystic Fibrosis Center, University Medical Center Utrecht, Utrecht, the Netherlands
}

Corresponding author:

Hulzebos H.J.,

Child Development \& Exercise Center

University Medical Center Utrecht

P.O. Box 85090

3508 AB Utrecht

The Netherlands.

Phone $+31887554030 /$ Fax +310887555333

E-mail: $\underline{H . H u l z e b o s @ u m c u t r e c h t . n l}$

Running title: Is static hyperinflation a limiting factor during exercise in CF? 
Is static hyperinflation a limiting factor during exercise in CF?

\begin{abstract}
Summary
Increased work of breathing is considered to be a limiting factor in patients with Cystic Fibrosis (CF) performing aerobic exercise. We hypothesized that adolescents with $\mathrm{CF}$ and with static hyperinflation are more prone to a ventilatorily limited exercise capacity than nonstatic hyperinflated adolescents with CF.

Exercise data of 119 adolescents with CF [range 12-18 yrs.], stratified for static hyperinflation, defined as ratio of residual volume to total lung capacity (RV/TLC) $>30 \%$, were obtained during a progressive bicycle ergometer test with gas analysis and analyzed for ventilatory limitation.
\end{abstract}

Static hyperinflation showed a significant, though weak association $(\Phi 0.38 ; \mathrm{p}<.001)$ with a ventilatorily limited exercise capacity (Breathing Reserve Index at maximal effort $>0.70$; $\mathrm{FEV}_{1}<80 \%$ predicted and reduced exercise capacity, defined as $\mathrm{VO}_{2 \text { peak }}<85 \%$ predicted). Analysis of association for increasing degrees of hyperinflation showed an increase to $\Phi .49$ $(\mathrm{p}<.001)$ for RV/TLC $>50 \%$. In adolescents with static hyperinflation, peak work rate $\left(\mathrm{W}_{\text {peak }} ; 3.1 \pm 0.7 \mathrm{Watt} / \mathrm{kg}(75.1 \pm 17.3 \%\right.$ of predicted $)$, peak oxygen uptake $\left(\mathrm{VO}_{2 \text { peak }} / \mathrm{kg}\right.$ $(\mathrm{ml} / \mathrm{min} / \mathrm{kg}) ; 39.2 \pm 9.2 \mathrm{ml} / \mathrm{min} / \mathrm{kg}(91.0 \pm 20.3 \%$ of predicted $)$, peak heart rate $\left(\mathrm{HR}_{\text {peak }} ; 176 \pm 19\right.$ beats/min) were significantly $(\mathrm{p}<.05)$ decreased when compared with non-static hyperinflated adolescents $\left(\mathrm{W}_{\text {peak }} 3.5 \pm 0.5 \mathrm{Watt} / \mathrm{kg}(81.4 \pm 10.0 \%\right.$ of predicted $\left.)\right) ; \mathrm{VO}_{2 \text { peak }} / \mathrm{kg}$ $(\mathrm{ml} / \mathrm{min} / \mathrm{kg}) ; 43.1 \pm 7.5 \mathrm{ml} / \mathrm{min} / \mathrm{kg}(98.0 \pm 15.1 \%$ of predicted $)$ and $\mathrm{HR}_{\text {peak }} 185 \pm 14$ beats $\left./ \mathrm{min}\right)$. Additionally, no difference was found in the degree of association of $\mathrm{FEV}_{1}(\%)$ and RV/TLC (\%) with $\mathrm{VO}_{2 \text { peak }} / \mathrm{kg}_{\text {pred }}$ and $\mathrm{W}_{\text {peak }} / \mathrm{kg}_{\text {Pred }}$, but we found the $\mathrm{RV} / \mathrm{TLC}(\%)$ to be a slightly stronger predictor of $\mathrm{VO}_{2 \text { peak }} / \mathrm{kg}_{\text {pred }}$ and $\mathrm{W}_{\text {peak }} / \mathrm{kg}_{\text {Pred }}$ than $\mathrm{FEV}_{1}(\%)$.

These results indicate that the presence of static hyperinflation in adolescents with CF by itself does not strongly influence ventilatory constraints during exercise and that static 
Is static hyperinflation a limiting factor during exercise in CF?

hyperinflation is only a slightly stronger predictor of $\mathrm{W}_{\text {peak }} / \mathrm{kg}_{\text {Pred }}$ and $\mathrm{VO}_{2 \text { peak }} / \mathrm{kg}_{\text {Pred }}$ than airflow obstruction $\left(\mathrm{FEV}_{1}(\%)\right)$.

Keywords: work of breathing; ventilatory limitation; cardiopulmonary exercise testing 
Is static hyperinflation a limiting factor during exercise in CF?

\section{Introduction}

Limitation of exercise capacity in adolescents with cystic fibrosis (CF) has a multi-factorial cause. Reduced lung function and muscle mass are known to be most important factors leading to a limited exercise capacity. ${ }^{1,2}$ A decreased muscle mass reduces skeletal muscle function, including respiratory muscle strength, in adults with $\mathrm{CF}^{3}$ Moreover, in children with $\mathrm{CF}$ a decreased skeletal muscle strength ${ }^{4,5}$ and endurance ${ }^{6}$ have been reported, even when corrected for a decreased lean body mass or lung function. ${ }^{4-6}$ This points to a possible intrinsic abnormality in muscle oxygen uptake in patients with $\mathrm{CF}$, however, currently there is no firm evidence available. $^{7-11}$

Due to continuous airflow obstruction, as reflected by a decreased forced expiratory volume in one second $\left(\mathrm{FEV}_{1}\right)$, and dynamic hyperinflation, as reflected by a decreasing inspiratory capacity (IC) during exercise ${ }^{12}$, children with CF develop a rapid breathing pattern during exercise with a concomitant increase in the work of breathing (WOB) ${ }^{13-15}$ and oxygen cost. ${ }^{13}$ A decreased inspiratory muscle function (strength and endurance) that has been observed in patients with CF will lead to a faster inspiratory muscle fatigue during exercise, which contributes to the reduced exercise capacity. ${ }^{16} 17$

It seems that there is an interrelationship between lung function, muscle mass, energy expenditure, (respiratory) muscle function and exercise capacity in patients with $\mathrm{CF}^{18}$ The objective of the current study was to investigate whether static hyperinflation makes adolescents with CF more prone to a ventilatory limitation during exercise. We hypothesized that adolescents with static hyperinflation are more prone to a ventilatorily limited exercise capacity than non-static hyperinflated adolescents with CF. Furthermore, we questioned if the amount of static hyperinflation (RV/TLC (\%)) is a stronger predictor of exercise capacity than the degree of airflow obstruction $\mathrm{FEV}_{1}$ (\%pred). 
Is static hyperinflation a limiting factor during exercise in CF?

\section{Materials and Methods}

\section{Subjects}

Adolescents with CF $(n=119)$ of the Cystic Fibrosis Center of the University Children's Hospital and Medical Center Utrecht, the Netherlands, were measured for body weight, height, lung function and exercise capacity as part of routine assessment measures at the annual medical check-up. All measurements were part of usual care, according to the policy of the medical ethical committee of the University Medical Center Utrecht, ethical approval and informed consent were not obliged. Data of the initial test of each participant (between 1998 and 2006) were selected for this study. Participants were stratified into static hyperinflated and non-static hyperinflated. Conform previous literature about children with asthma, we defined a ratio of residual volume to total lung capacity (RV/TLC), after using a bronchodilator, higher than $30 \%$ as moderate to severe hyperinflation. ${ }^{19}$ Analysis for increasing degrees of static hyperinflation was performed by including only patients with a certain level of static hyperinflation in the analysis (RV/TLC $>30 \%,>35 \%,>40 \%,>45 \%$ and $>50 \%$ ).

The definition used for determination of a ventilatory limitation during Cardio Pulmonary Exercise Test (CPET) was previously used by Sexauer et al, including: [1] Breathing Reserve Index at maximal effort $>0.70$ (Calculated as peak minute ventilation $\left(\mathrm{VE}_{\text {peak }}\right)$ divided by maximal voluntary ventilation (MVV) were MVV is calculated as $35 \mathrm{xFV}_{1}$ ), [2] a $\mathrm{FEV}_{1}<$ $80 \%$ predicted and [3] a reduced exercise capacity, defined as $\mathrm{VO}_{2 \text { peak }}<85 \%$ predicted. ${ }^{20}$

\section{Spirometry}

Spirometry and body plethysmography were performed before and after bronchodilation with salbutamol (800 ug), using a pneumotach system and a volume-constant plethysmograph (Master Lab system, E. Jaeger, Würzburg, Germany). 
Is static hyperinflation a limiting factor during exercise in CF?

Lung function measurements included total lung capacity (TLC), residual volume (RV) and forced expiratory volume in 1 second $\left(\mathrm{FEV}_{1}\right)$. The results were compared with predicted values for healthy subjects matched for age, body height, and gender. ${ }^{21}$

\section{Cardiopulmonary exercise test (CPET)}

Exercise capacity was assessed using a progressive cardiopulmonary exercise test (CPET). CPET, after brochodilation with salbutamol, performed on an electronically braked cycle ergometer (Jaeger physis; Carefusion, Houten, The Netherlands). The seat height was adjusted to the participant's comfort and leg length. Participants rested until all measured variables were stable. Cycling started at a workload of $0 \mathrm{~W}$; the workload was incremented with $15 \mathrm{~W} / \mathrm{min}$ until the patient stopped due to volitional exhaustion. The workload which could be overcome for the last 30 seconds prior to exhaustion was considered to be the $\mathrm{W}_{\text {peak }}$. Determination if a participants' effort was maximal was based on subjective and objective criteria. Subjective criteria are described as "unsteady biking", "sweating", "facial flushing" and "clear unwillingness to continue despite encouragement". Objective criteria were: [1] peak heart rate $(\mathrm{HR})>95 \% \mathrm{HR}_{\text {predicted }}(210$-age $)$ and [2] respiratory exchange ratio (RER) $>$ 1.00. Based on previous literature, we defined that a participant had to meet the subjective criteria and at least 1 out of two objective criteria for the test to be considered of maximal effort and character. ${ }^{22}$ Participants breathed through a mask that was connected to a calibrated metabolic cart (Oxycon pro, Carefusion, Houten, The Netherlands). Expired gas was passed through a flow meter, oxygen analyzer, and a carbon dioxide analyzer. The flow meter and gas analyzer were connected to a computer, which calculated breath-by-breath minute ventilation $(\mathrm{VE})$, oxygen uptake $\left(\mathrm{VO}_{2}\right)$, carbon dioxide production $\left(\mathrm{VCO}_{2}\right)$ and respiratory exchange ratio (RER) from conventional equations. Relative peak oxygen uptake $\left(\mathrm{VO}_{2 \text { peak }} / \mathrm{kg}\right)$ 
Is static hyperinflation a limiting factor during exercise in CF?

was calculated by dividing $\mathrm{VO}_{2 \text { peak }}$ by total body mass. Heart rate was monitored continuously by a 3-lead electrocardiogram (Hewlett-Packard, Amstelveen, Netherlands).

\section{Reference values}

Reference values for $\mathrm{VO}_{2 \text { peak }}$ and $\mathrm{W}_{\text {peak }}$ from healthy children and adolescents were obtained from previously studied Dutch children and adolescents. ${ }^{23,24}$

\section{Statistical analysis}

Data were expressed as mean \pm SD. Data were analyzed using SPSS 15.0 for Windows and tested for normality with the Kolmogorov-Smirnov Test. An alpha value of 0.05 was considered as statistically significant. Possible differences between groups in the CFpopulation were analyzed using one-way ANOVA when normally distributed and with the Mann-Whitney U-Test when not normally distributed. Dichotomy variables were tested for association using the phi coefficient $(\Phi)$, and tested for significance using Chi-square test. Prognostic value of $\mathrm{FEV}_{1}$ and RV/TLC for exercise capacity was analyzed using standard multiple regression analysis. 
Is static hyperinflation a limiting factor during exercise in CF?

\section{Results}

\section{Study Group Demographics}

After determination of maximal effort and screening for completeness of data set, in total 119 adolescents, 50 females and 69 males were included.

Mean age was 13.8 years \pm 1.7 (range $12-18$ years), with a mean $\mathrm{FEV}_{1}$ of $82.9 \% \pm 20.9(\%$ predicted). $\mathrm{FEV}_{1}$ and anthropometric values did not differ according to gender (Table 1). All measurements were obtained after bronchodilator.

$<$ Please, insert TABLE 1 about here $>$

\section{Static hyperinflation versus non-static hyperinflation}

Overall, 54 (40.3\%) patients were non-static hyperinflated (20; 34§ో; RV/TLC (\%)

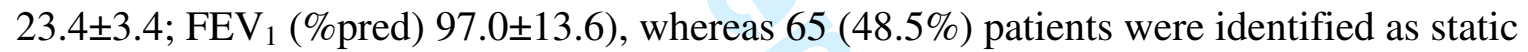

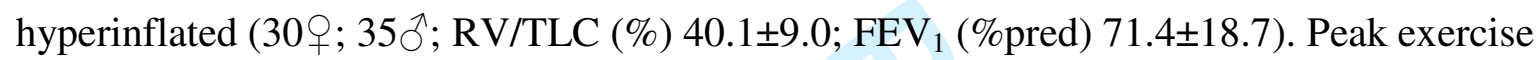
parameters and ventilatory parameters in static hyperinflated and non-static hyperinflated adolescents with $\mathrm{CF}$ are shown in Table $2 . \mathrm{VO}_{2 \text { peak }} / \mathrm{kg}, \mathrm{W}_{\text {peak }} / \mathrm{kg}, \mathrm{VE}_{\text {peak }}$ and $\mathrm{HR}_{\text {peak }}$ were all significantly lower in static hyperinflated patients compared to the non-hyperinflated patients $(\mathrm{p}<0.05)$. Corrected for age and gender, the differences in $\mathrm{VO}_{2 \text { peak }} / \mathrm{kg}_{\text {Pred }}(98.0 \pm 15.1 \%$ in non-static hyperinflated and $91.0 \pm 20.3 \%$ in static hyperinflated patients; $\mathrm{p}<.05$ ), and in $\mathrm{W}_{\text {peak }} / \mathrm{kg}_{\text {Pred }}(75.1 \pm 17.3(\%)$ in static hyperinflated and $81.4 \pm 10.0(\%)$ in non-static hyperinflated patients; $\mathrm{p}<.05$ ) remained (Table 2 ).

$<$ Please, insert TABLE 2 about here $>$ 
Is static hyperinflation a limiting factor during exercise in CF?

\section{Ventilatory versus Non-ventilatory limitation}

Twenty $(29.4 \% ; 7+; 13 \hat{\jmath})$ out of the 65 patients with static hyperinflation were ventilatorily limited during exercise while only $1\left(1 \jmath^{\Uparrow}\right)$ of the 54 patients without static hyperinflation was ventilatorily limited during exercise. Phi coefficient $(\Phi)$ between ventilatory limitation and static hyperinflation was 0.38 ( $p<0.001$; see Table 3$)$. Furthermore, for increasing degrees of hyperinflation, Phi coefficient increased to $.52(\mathrm{p}<.001)$ in the RV/TLC range $30 \%-50 \%$. (Table 3)

$<$ Please, insert TABLE 3 about here $>$

\section{Lung function and exercise capacity}

As presented in Figure 1, baseline $\mathrm{FEV}_{1}$ (\% \%red) after bronchodilator, showed a fair degree of association with $\mathrm{VO}_{2 \text { peak }} / \mathrm{kg}_{\text {Pred }}$ and $\mathrm{W}_{\text {peak }} / \mathrm{kg}_{\text {Pred }}(\mathrm{r}=.44$ and $\mathrm{r}=.46$ respectively (both $\mathrm{p}<$ .001), where RV/TLC, after bronchodilator, showed more variable degrees of association $(\mathrm{r}=$ -.43 and $\mathrm{r}=-.47$ respectively (both $\mathrm{p}<.001)$ after bronchodilator). There was a strong association between $\mathrm{FEV}_{1}$ (\%pred) and RV/TLC after bronchodilator $(\mathrm{r}=-.84 ; \mathrm{p}<.001)$. Multiple linear regression showed that, compared to FEV1 (\%pred), RV/TLC (\%) was a somewhat stronger predictor for $\mathrm{W}_{\text {peak }} / \mathrm{kg}_{\text {Pred }}(\mathrm{FEV} 1$ (\%pred) B .161 and $\mathrm{B} .227(\mathrm{p}=.135))$; RV/TLC (\%) B -.371 and B -.273 (p = .073)) and $\mathrm{VO}_{2 \text { peak }} / \mathrm{kg}_{\text {Pred }}(\mathrm{RV} / \mathrm{TLC}(\%) \mathrm{B}-.343$ and $\beta$ $.203(\mathrm{p}=.188) ; \mathrm{FEV}_{1}(\%$ pred $)$ B .239 and $\left.\beta .272(\mathrm{p}=.078)\right)$.

$<$ Please, insert FIG.1 about here $>$ 
Is static hyperinflation a limiting factor during exercise in CF?

\section{Discussion}

We hypothesized that adolescents with CF with static hyperinflation are more prone for a ventilatorily limited aerobic exercise capacity compared with non-static hyperinflated adolescents. We found a significant, but weak association $(\Phi 0.38 ; \mathrm{p}<0.001)$ between static hyperinflation (RV/TLC $>30 \%)$ and ventilatory limitation at peak exercise. This indicates that the presence of static hyperinflation in adolescents with CF by itself does not strongly influence ventilatory constraints during exercise, which is in line with previous research. ${ }^{20}$ Sexauer et al found an odds ratio of $0.96(\mathrm{p}=0.76)$ for the RV/TLC ratio at rest as a weak non-significant predictor for ventilatory limitation in adults with $\mathrm{CF} .{ }^{20}$ Confirmative results were found in a study among adult COPD patients, were the change in inspiratory capacity (IC) during exercise, reflecting dynamic hyperinflation, has been shown to be superior to static hyperinflation (resting IC) in estimating exercise tolerance. ${ }^{25}$ Moreover, after analysis of the association between the degrees of static hyperinflation and a ventilatorily limited exercise capacity, the correlation coefficient slightly increased from .38 to .49 for $\mathrm{RV} / \mathrm{TLC}>30 \%$ and $>50 \%$, respectively.

Additionally, we found no difference in the degree of association of baseline $\mathrm{FEV}_{1}$ (\%pred) and RV/TLC (\%), after bronchodilator, with $\mathrm{VO}_{2 \text { peak }} / \mathrm{kg}_{\text {Pred. }}$ and $\mathrm{W}_{\text {peak }} / \mathrm{kg}_{\text {Pred }}$, however, RV/TLC (\%) was a slightly stronger predictor of $\mathrm{VO}_{2 \text { peak }} / \mathrm{kg}_{\text {Pred. }}$ and $\mathrm{W}_{\text {peak }} / \mathrm{kg}_{\text {Pred }}$ than $\mathrm{FEV}_{1}$ (\%pred).

A point of discussion in the present study is the cut-off point in breathing reserve used to determine ventilatory limitation. Prioux et al suggested a ventilatory reserve at peak exercise of $20 \%$ (MVV-VE / MVV x 100\%), with a corresponding breathing reserve 0.8, in 11- yearold children, which increased to $30 \%$ (corresponding breathing reserve 0.7 ) at the age of 16 years. The mean age of our patients is 14 years, which could have influenced the prevalence of ventilatory limitation as we have used breathing reserve $>0.7$ as cut-off point. ${ }^{26}$ 
Is static hyperinflation a limiting factor during exercise in CF?

Furthermore, due to the narrow age range of our population, the present results could not be extrapolated to patients that are younger or older.

Based on the results we conclude that the presence of static hyperinflation after bronchodilator (RV/TLC $>30 \%)$ in adolescents with CF by itself does not strongly influence ventilatory constraints during exercise and that static hyperinflation, as reflected by RV/TLC $(\%)$, is only a slightly stronger predictor of $\mathrm{W}_{\text {peak }} / \mathrm{kg}_{\text {Pred }}$ and $\mathrm{VO}_{2 \text { peak }} / \mathrm{kg}_{\text {Pred }}$ than the $\mathrm{FEV}_{1}$ (\%pred), which is only reflecting the degree of airflow obstruction. The decreased exercise capacity in static hyperinflated adolescents could be explained by faster termination of peak exercise due to preliminary inspiratory muscle fatigue. The preliminary inspiratory muscle fatigue could be induced by the development of dynamic hyperinflation. ${ }^{14,15,24}$, which increases work ${ }^{12-15}$ and oxygen cost of breathing ${ }^{13}$ and causing intrapulmonary gas trapping and ventilation/perfusion mismatching ${ }^{27}$, which make a patient with $\mathrm{CF}$ more susceptible to ventilatory limitation during exercise. ${ }^{15}$ Moreover, the greater fatigability of the inspiratory muscles could hypothetically induce a reflex vasoconstriction in the peripheral locomotor muscles and thereby compromises blood flow to the exercising limbs. ${ }^{17}$ Furthermore, the increase in work of breathing in patients with $\mathrm{CF}$ as a possible factor in ventilatorily limited exercise capacity could theoretically be elicited by the development of dynamic hyperinflation during exercise, instead of the presence of static hyperinflation at rest.

Beside the $\mathrm{FEV}_{1}$ and possible dynamic hyperinflation, other factors, such as nutritional status, muscle mass, respiratory and peripheral muscle strength and habitual daily physical activity are also important predictors of exercise capacity. $1,2,4,28$

After all we suggest that, in future research, beside standard anthropometric and lung function measures, dynamic hyperinflation and flow-volume curves during exercise should be measured to facilitate a better understanding of the role of increased work of breathing as possible limiting factor in the exercise capacity of patients with $\mathrm{CF}$. 
Is static hyperinflation a limiting factor during exercise in CF?

\section{Acknowledgments}

This study was funded by an unconditional research grant (DO-IT) from the Committee on Physiotherapy Research of the Royal Dutch Society for Physiotherapy (Wetenschappelijk College Fysiotherapie, Koninklijk Nederlands Genootschap voor Fysiotherapie (KNGF)). All measurements used in data analysis are part of standard routine care at the Cystic Fibrosis Center of the University Children's Hospital and Medical Center Utrecht, Utrecht, the Netherlands. 
Is static hyperinflation a limiting factor during exercise in CF?

\section{References}

1. Shah AR, Gozal D, Keens TG. Determinants of aerobic and anaerobic exercise performance in cystic fibrosis. Am J Respir Crit Care Med 1998;157:1145-1150.

2. Klijn PHC, Net van der J, Kimpen JL, Helders PJM, Ent van der CK. Longitudinal determinants of peak aerobic performance in children with cystic fibrosis. Chest 2003;124(6):2215-2219.

3. Ionescu AA, Chatham K, Davies CA, Nixon LS, Enright S, Shale DJ. Inspiratory muscle function and body composition in cystic fibrosis. Am J Respir Crit Care Med 1998;158(4):1271-1276.

4. Meer de K, Gulmans VAM, Laag van der J. Peripheral muscle weakness and exercise capacity in children with cystic fibrosis. Am J Respir Crit Care Med 1999;159(3):748754.

5. Hussey J, Gormley J, Leen G, Greally P. Peripheral muscle strength in young males with cystic fibrosis. Journal of Cystic Fibrosis 2002(3);1:116-121.

6. Sahlberg ME, Svantesson U, Magnusson Thomas EML, Strandvik B. Muscular strength and function in patients with cystic fibrosis. Chest 2005;127(5):1587-1592.

7. Moser C, Tirakitsoontorn P, Nussbaum E, Newcomb R, Cooper DM. Muscle size and cardiorespiratory response to exercise in cystic fibrosis. Am J Respir Crit Care Med 2000;162(5):1823-1827. 
Is static hyperinflation a limiting factor during exercise in CF?

8. Meer de K, Jeneson JAL, Gulmans VAM, Laag van der J, Berger R. Efficiency of oxidative work performance of skeletal muscle in patients with cystic fibrosis. Thorax 1995;50(9):980-983.

9. Hjeltnes N, Stanghelle JK, Skyberg D. Pulmonary function and oxygen uptake during exercise in 16 year old boys with cystic fibrosis. Acta Paediatr Scand 1984;73(4):548553.

10. Hebestreit H, Hebestreit A, Trusen A, Hughson RL. Oxygen uptake kinetics are slowed in cystic fibrosis. Med Sci Sports Exerc 2005;37:10-17.

11. Rosenthal M, Narang I, Edwards L, Bush A. Non-invasive assessment of exercise performance in children with cystic fibrosis $(\mathrm{CF})$ and non-cystic fibrosis bronchiectasis: is there a CF specific muscle defect? Pediatr Pulmonol 2009;44(3):222-230.

12. Loring SH, Garcia-Jaques M, Malhotra A. Pulmonary characteristics in COPD and mechanisms of increased work of breathing. J Appl Physiol 2009;107(1):309-314.

13. Gibson GJ. Pulmonary hyperinflation a clinical overview. Eur Respir J 1996;9:26402649.

14. Keochkerian D, Chlif M, Delanaud S, Gauthier R, Maingourd Y, Ahmaidi S. Timing and driving components of the breathing strategy in children with cystic fibrosis during exercise. Pediatric Pulmonology 2005;40(5):449-456. 
Is static hyperinflation a limiting factor during exercise in CF?

15. Keochkerian D, Chlif M, Delanaud S, Gauthier R, Maingourd Y, Ahmaidi S. Breathing pattern adopted by children with cystic fibrosis with mild to moderate pulmonary impairment during exercise. Respiration 2008;75(2):170-177.

16. Enright S, Chatham K, Ionescu AA, Unnithan VB, Shale DJ. Inspiratory muscle training improves lung function and exercise capacity in adults with cystic fibrosis. Chest 2004;126(2):405-411.

17. Dempsey JA, Romer L, Rodmann J, Miller J, Smith C. Consequences of exerciseinduced respiratory muscle work. Respiratory Physiology \& Neurobiology 2006;151(2-3):242-250.

18. Schöni MH, Casaulta-Aebischer C. Nutrition and lung function in cystic fibrosis patients: review. Clinical Nutrition 2000;19(2):79-85.

19. Eid N, Yandell B, Howell L, Eddy M, Sheikh S. Can peak expiratory flow predict airflow obstruction in children with asthma? Pediatrics 2000;105(2):354-358.

20. Sexauer WP, Cheng H-K, Fiel SB. Utility of the breathing reserve index at the anaerobic threshold in determining ventilatory-limited exercise in adult cystic fibrosis patients. Chest 2003;124(4):1469-1475.

21. Zapletal, A., M. Samanek, and T. Paul. 1987. Lung function in children and adolescents: methods, reference values. In A. Zapletal, editor. Progress in Respiration Research. Karger, Basel. 22:114-218. 
Is static hyperinflation a limiting factor during exercise in CF?

22. de Groot JF, Takken T, de Graaff S, Gooskens RHJM, Helders PJM, Vanhees L: Treadmill testing of children who have spina bifida and are ambulatory: Does peak oxygen uptake reflect maximum oxygen uptake? Phys Ther 2009: 89: 679-687.

23. Gulmans VA, Meer K de, Binkhorst RA, Helders PJ, Saris WH. Reference values for maximum work capacity in relation to body composition in healthy Dutch children. Eur Respir J 1997;10(1):94-97.

24. Saris WHM, Noordeloos AM, Rignalda BEM, Hof van't MA, Binkhorst RA. Reference values for aerobic power of healthy 4 to 18 year old Dutch children. In: Binkhorst RA, Kemper HGC, Saris WHM, eds. Children and exercise. XI. International Series on Sport Sciences, Vol. 15. Champaign, IL, USA, Human Kinetics, 1985; pp. 151-160.

25. O'Donnell DE, Revill SM, Webb KA. Dynamic hyperinflation and exercise intolerance in chronic obstructive pulmonary disease. Am J Respir Crit Care Med 2001;164:770-777.

26. Prioux J, Matecki S, Amsallem F, Denjean A, Ramonatxo M et al. La response ventilatoire à l'exercise maximal chez l'enfant sain. Rev Mal Respir 2003;20:904-911.

27. Hart N, Polkey MI, Clément A et al. Changes in pulmonary mechanics with increasing disease severity in children and young adults with cystic fibrosis. Am J Respir Crit Care Med 2002;166(1):61-66. 
Is static hyperinflation a limiting factor during exercise in CF?

28. Lands L, Desmond KJ, Demizio D, Pavilanis A, Coates AL. The effects of nutritional status and hyperinflation on respiratory muscle strength in children and young adults. Am Rev of Respir Dis 1990;141(6):1506-1509. 
Is static hyperinflation a limiting factor during exercise in CF?

\section{Figure Captions}

Fig. 1. Associations between lung function parameters and exercise capacity. 
Is static hyperinflation a limiting factor during exercise in $\mathrm{CF}$ ?

\section{Introduction}

Limitation of exercise capacity in adolescents with cystic fibrosis (CF) has a multi-factorial cause. Reduced lung function and muscle mass are known to be most important factors leading to a limited exercise capacity. ${ }^{1,2}$ A decreased muscle mass reduces skeletal muscle function, including respiratory muscle strength, in adults with $\mathrm{CF}^{3}$ Moreover, in children with $\mathrm{CF}$ a decreased skeletal muscle strength ${ }^{4,5}$ and endurance ${ }^{6}$ have been reported, even when corrected for a decreased lean body mass or lung function. ${ }^{4-6}$ This points to a possible intrinsic abnormality in muscle oxygen uptake in patients with $\mathrm{CF}$, however, currently there is no firm evidence available. $^{7-11}$

Due to continuous airflow obstruction, as reflected by a decreased forced expiratory volume in one second $\left(\mathrm{FEV}_{1}\right)$, and dynamic hyperinflation, as reflected by a decreasing inspiratory capacity (IC) during exercise ${ }^{12}$, children with CF develop a rapid breathing pattern during exercise with a concomitant increase in the work of breathing (WOB) ${ }^{13-15}$ and oxygen cost. ${ }^{13}$ A decreased inspiratory muscle function (strength and endurance) that has been observed in patients with CF will lead to a faster inspiratory muscle fatigue during exercise, which contributes to the reduced exercise capacity. ${ }^{16} 17$

It seems that there is an interrelationship between lung function, muscle mass, energy expenditure, (respiratory) muscle function and exercise capacity in patients with $\mathrm{CF}^{18}$ The objective of the current study was to investigate whether static hyperinflation makes adolescents with CF more prone to a ventilatory limitation during exercise. We hypothesized that adolescents with static hyperinflation are more prone to a ventilatorily limited exercise capacity than non-static hyperinflated adolescents with CF. Furthermore, we questioned if the amount of static hyperinflation (RV/TLC (\%)) is a stronger predictor of exercise capacity than the degree of airflow obstruction $\mathrm{FEV}_{1}$ (\%pred). 
Is static hyperinflation a limiting factor during exercise in CF?

\section{Materials and Methods}

\section{Subjects}

Adolescents with CF $(n=119)$ of the Cystic Fibrosis Center of the University Children's Hospital and Medical Center Utrecht, the Netherlands, were measured for body weight, height, lung function and exercise capacity as part of routine assessment measures at the annual medical check-up. All measurements were part of usual care, according to the policy of the medical ethical committee of the University Medical Center Utrecht, ethical approval and informed consent were not obliged. Data of the initial test of each participant (between 1998 and 2006) were selected for this study. Participants were stratified into static hyperinflated and non-static hyperinflated. Conform previous literature about children with asthma, we defined a ratio of residual volume to total lung capacity (RV/TLC), after using a bronchodilator, higher than $30 \%$ as moderate to severe hyperinflation. ${ }^{19}$ Analysis for increasing degrees of static hyperinflation was performed by including only patients with a certain level of static hyperinflation in the analysis (RV/TLC $>30 \%,>35 \%,>40 \%,>45 \%$ and $>50 \%$ ).

The definition used for determination of a ventilatory limitation during Cardio Pulmonary Exercise Test (CPET) was previously used by Sexauer et al, including: [1] Breathing Reserve Index at maximal effort $>0.70$ (Calculated as peak minute ventilation $\left(\mathrm{VE}_{\text {peak }}\right)$ divided by maximal voluntary ventilation (MVV) were MVV is calculated as $35 \mathrm{xFV}_{1}$ ), [2] a $\mathrm{FEV}_{1}<$ $80 \%$ predicted and [3] a reduced exercise capacity, defined as $\mathrm{VO}_{2 \text { peak }}<85 \%$ predicted. ${ }^{20}$

\section{Spirometry}

Spirometry and body plethysmography were performed before and after bronchodilation with salbutamol (800 ug), using a pneumotach system and a volume-constant plethysmograph (Master Lab system, E. Jaeger, Würzburg, Germany). 
Is static hyperinflation a limiting factor during exercise in $\mathrm{CF}$ ?

Lung function measurements included total lung capacity (TLC), residual volume (RV) and forced expiratory volume in 1 second $\left(\mathrm{FEV}_{1}\right)$. The results were compared with predicted values for healthy subjects matched for age, body height, and gender. ${ }^{21}$

\section{Cardiopulmonary exercise test (CPET)}

Exercise capacity was assessed using a progressive cardiopulmonary exercise test (CPET). CPET, after brochodilation with salbutamol, performed on an electronically braked cycle ergometer (Jaeger physis; Carefusion, Houten, The Netherlands). The seat height was adjusted to the participant's comfort and leg length. Participants rested until all measured variables were stable. Cycling started at a workload of $0 \mathrm{~W}$; the workload was incremented with $15 \mathrm{~W} / \mathrm{min}$ until the patient stopped due to volitional exhaustion. The workload which could be overcome for the last 30 seconds prior to exhaustion was considered to be the $\mathrm{W}_{\text {peak }}$. Determination if a participants' effort was maximal was based on subjective and objective criteria. Subjective criteria are described as "unsteady biking", "sweating", "facial flushing" and "clear unwillingness to continue despite encouragement". Objective criteria were: [1] peak heart rate $(\mathrm{HR})>95 \% \mathrm{HR}_{\text {predicted }}(210$-age) and [2] respiratory exchange ratio (RER) $>$ 1.00. Based on previous literature, we defined that a participant had to meet the subjective criteria and at least 1 out of two objective criteria for the test to be considered of maximal effort and character. ${ }^{22}$ Participants breathed through a mask that was connected to a calibrated metabolic cart (Oxycon pro, Carefusion, Houten, The Netherlands). Expired gas was passed through a flow meter, oxygen analyzer, and a carbon dioxide analyzer. The flow meter and gas analyzer were connected to a computer, which calculated breath-by-breath minute ventilation $(\mathrm{VE})$, oxygen uptake $\left(\mathrm{VO}_{2}\right)$, carbon dioxide production $\left(\mathrm{VCO}_{2}\right)$ and respiratory exchange ratio (RER) from conventional equations. Relative peak oxygen uptake $\left(\mathrm{VO}_{2 \text { peak }} / \mathrm{kg}\right)$ 
Is static hyperinflation a limiting factor during exercise in CF?

was calculated by dividing $\mathrm{VO}_{2 \text { peak }}$ by total body mass. Heart rate was monitored continuously by a 3-lead electrocardiogram (Hewlett-Packard, Amstelveen, Netherlands).

\section{Reference values}

Reference values for $\mathrm{VO}_{2 \text { peak }}$ and $\mathrm{W}_{\text {peak }}$ from healthy children and adolescents were obtained from previously studied Dutch children and adolescents. ${ }^{23,24}$

\section{Statistical analysis}

Data were expressed as mean \pm SD. Data were analyzed using SPSS 15.0 for Windows and tested for normality with the Kolmogorov-Smirnov Test. An alpha value of 0.05 was considered as statistically significant. Possible differences between groups in the CFpopulation were analyzed using one-way ANOVA when normally distributed and with the Mann-Whitney U-Test when not normally distributed. Dichotomy variables were tested for association using the phi coefficient $(\Phi)$, and tested for significance using Chi-square test. Prognostic value of $\mathrm{FEV}_{1}$ and RV/TLC for exercise capacity was analyzed using standard multiple regression analysis. 
Is static hyperinflation a limiting factor during exercise in $\mathrm{CF}$ ?

\section{Results}

Study Group Demographics

After determination of maximal effort and screening for completeness of data set, in total 119 adolescents, 50 females and 69 males were included.

Mean age was 13.8 years \pm 1.7 (range $12-18$ years), with a mean $\mathrm{FEV}_{1}$ of $82.9 \% \pm 20.9(\%$ predicted). $\mathrm{FEV}_{1}$ and anthropometric values did not differ according to gender (Table 1). All measurements were obtained after bronchodilator.

$<$ Please, insert TABLE 1 about here $>$

\section{Static hyperinflation versus non-static hyperinflation}

Overall, 54 (40.3\%) patients were non-static hyperinflated (20; 34§ో; RV/TLC (\%)

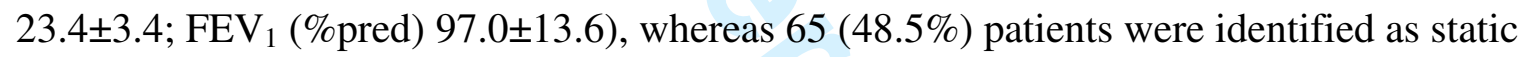

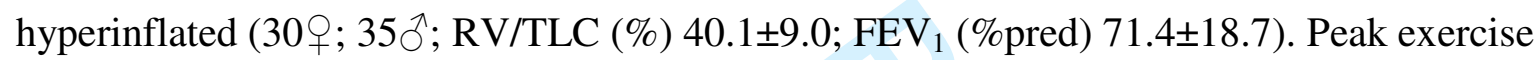
parameters and ventilatory parameters in static hyperinflated and non-static hyperinflated adolescents with $\mathrm{CF}$ are shown in Table $2 . \mathrm{VO}_{2 \text { peak }} / \mathrm{kg}, \mathrm{W}_{\text {peak }} / \mathrm{kg}, \mathrm{VE}_{\text {peak }}$ and $\mathrm{HR}_{\text {peak }}$ were all significantly lower in static hyperinflated patients compared to the non-hyperinflated patients $(\mathrm{p}<0.05)$. Corrected for age and gender, the differences in $\mathrm{VO}_{2 \text { peak }} / \mathrm{kg}_{\text {Pred }}(98.0 \pm 15.1 \%$ in non-static hyperinflated and $91.0 \pm 20.3 \%$ in static hyperinflated patients; $\mathrm{p}<.05$ ), and in $\mathrm{W}_{\text {peak }} / \mathrm{kg}_{\text {Pred }}(75.1 \pm 17.3(\%)$ in static hyperinflated and $81.4 \pm 10.0(\%)$ in non-static hyperinflated patients; $\mathrm{p}<.05$ ) remained (Table 2 ).

$<$ Please, insert TABLE 2 about here $>$ 
Is static hyperinflation a limiting factor during exercise in $\mathrm{CF}$ ?

\section{Ventilatory versus Non-ventilatory limitation}

Twenty $(29.4 \% ; 7 q ; 13 \AA)$ out of the 65 patients with static hyperinflation were ventilatorily limited during exercise while only $1\left(1 \jmath^{\Uparrow}\right)$ of the 54 patients without static hyperinflation was ventilatorily limited during exercise. Phi coefficient $(\Phi)$ between ventilatory limitation and static hyperinflation was 0.38 ( $p<0.001$; see Table 3$)$. Furthermore, for increasing degrees of hyperinflation, Phi coefficient increased to $.52(\mathrm{p}<.001)$ in the RV/TLC range $30 \%-50 \%$. (Table 3)

$<$ Please, insert TABLE 3 about here $>$

\section{Lung function and exercise capacity}

As presented in Figure 1, baseline $\mathrm{FEV}_{1}$ (\% \%red) after bronchodilator, showed a fair degree of association with $\mathrm{VO}_{2 \text { peak }} / \mathrm{kg}_{\text {Pred }}$ and $\mathrm{W}_{\text {peak }} / \mathrm{kg}_{\text {Pred }}(\mathrm{r}=.44$ and $\mathrm{r}=.46$ respectively (both $\mathrm{p}<$ $.001)$, where RV/TLC, after bronchodilator, showed more variable degrees of association $(\mathrm{r}=$ -.43 and $\mathrm{r}=-.47$ respectively (both $\mathrm{p}<.001)$ after bronchodilator). There was a strong association between $\mathrm{FEV}_{1}$ (\%pred) and RV/TLC after bronchodilator $(\mathrm{r}=-.84 ; \mathrm{p}<.001)$. Multiple linear regression showed that, compared to FEV1 (\%pred), RV/TLC (\%) was a somewhat stronger predictor for $\mathrm{W}_{\text {peak }} / \mathrm{kg}_{\text {Pred }}(\mathrm{FEV} 1$ (\%pred) B .161 and $\mathrm{B} .227(\mathrm{p}=.135)$ ); RV/TLC (\%) B -.371 and $\beta-.273(\mathrm{p}=.073)$ ) and $\mathrm{VO}_{2 \text { peak }} / \mathrm{kg}_{\text {Pred }}(\mathrm{RV} / \mathrm{TLC}(\%) \mathrm{B}-.343$ and $\mathrm{B}-$ $.203(\mathrm{p}=.188) ; \mathrm{FEV}_{1}(\%$ pred $)$ B .239 and $\left.\beta .272(\mathrm{p}=.078)\right)$

$<$ Please, insert FIG.1 about here $>$ 
Is static hyperinflation a limiting factor during exercise in $\mathrm{CF}$ ?

\section{Discussion}

We hypothesized that adolescents with CF with static hyperinflation are more prone for a ventilatorily limited aerobic exercise capacity compared with non-static hyperinflated adolescents. We found a significant, but weak association $(\Phi 0.38 ; \mathrm{p}<0.001)$ between static hyperinflation (RV/TLC $>30 \%)$ and ventilatory limitation at peak exercise. This indicates that the presence of static hyperinflation in adolescents with CF by itself does not strongly influence ventilatory constraints during exercise, which is in line with previous research. ${ }^{20}$ Sexauer et al found an odds ratio of $0.96(\mathrm{p}=0.76)$ for the RV/TLC ratio at rest as a weak non-significant predictor for ventilatory limitation in adults with $\mathrm{CF} .{ }^{20}$ Confirmative results were found in a study among adult COPD patients, were the change in inspiratory capacity (IC) during exercise, reflecting dynamic hyperinflation, has been shown to be superior to static hyperinflation (resting IC) in estimating exercise tolerance. ${ }^{25}$

Moreover, after analysis of the association between the degrees of static hyperinflation and a ventilatorily limited exercise capacity, the correlation coefficient slightly increased from .38 to .49 for $\mathrm{RV} / \mathrm{TLC}>30 \%$ and $>50 \%$, respectively.

Additionally, we found no difference in the degree of association of baseline $\mathrm{FEV}_{1}$ (\%pred) and $\mathrm{RV} / \mathrm{TLC}(\%)$, after bronchodilator, with $\mathrm{VO}_{2 \text { peak }} / \mathrm{kg}_{\text {Pred. }}$ and $\mathrm{W}_{\text {peak }} / \mathrm{kg}_{\text {Pred }}$, however, $\mathrm{RV} / \mathrm{TLC}(\%)$ was a slightly stronger predictor of $\mathrm{VO}_{2 \text { peak }} / \mathrm{kg}_{\text {Pred. }}$ and $\mathrm{W}_{\text {peak }} / \mathrm{kg}_{\text {Pred }}$ than $\mathrm{FEV}_{1}$ (\%pred).

A point of discussion in the present study is the cut-off point in breathing reserve used to determine ventilatory limitation. Prioux et al suggested a ventilatory reserve at peak exercise of $20 \%$ (MVV-VE / MVV x 100\%), with a corresponding breathing reserve 0.8, in 11- yearold children, which increased to $30 \%$ (corresponding breathing reserve 0.7 ) at the age of 16 years. The mean age of our patients is 14 years, which could have influenced the prevalence of ventilatory limitation as we have used breathing reserve $>0.7$ as cut-off point. ${ }^{26}$ 
Is static hyperinflation a limiting factor during exercise in CF?

Furthermore, due to the narrow age range of our population, the present results could not be extrapolated to patients that are younger or older.

Based on the results we conclude that the presence of static hyperinflation after bronchodilator (RV/TLC $>30 \%$ ) in adolescents with CF by itself does not strongly influence ventilatory constraints during exercise and that static hyperinflation, as reflected by RV/TLC $(\%)$, is only a slightly stronger predictor of $\mathrm{W}_{\text {peak }} / \mathrm{kg}_{\text {Pred }}$ and $\mathrm{VO}_{2 \text { peak }} / \mathrm{kg}_{\text {Pred }}$ than the $\mathrm{FEV}_{1}$ (\%pred), which is only reflecting the degree of airflow obstruction. The decreased exercise capacity in static hyperinflated adolescents could be explained by faster termination of peak exercise due to preliminary inspiratory muscle fatigue. The preliminary inspiratory muscle fatigue could be induced by the development of dynamic hyperinflation. ${ }^{14,15,24}$, which increases work ${ }^{12-15}$ and oxygen cost of breathing ${ }^{13}$ and causing intrapulmonary gas trapping and ventilation/perfusion mismatching ${ }^{27}$, which make a patient with CF more susceptible to ventilatory limitation during exercise. ${ }^{15}$ Moreover, the greater fatigability of the inspiratory muscles could hypothetically induce a reflex vasoconstriction in the peripheral locomotor muscles and thereby compromises blood flow to the exercising limbs. ${ }^{17}$ Furthermore, the increase in work of breathing in patients with $\mathrm{CF}$ as a possible factor in ventilatorily limited exercise capacity could theoretically be elicited by the development of dynamic hyperinflation during exercise, instead of the presence of static hyperinflation at rest.

Beside the $\mathrm{FEV}_{1}$ and possible dynamic hyperinflation, other factors, such as nutritional status, muscle mass, respiratory and peripheral muscle strength and habitual daily physical activity are also important predictors of exercise capacity. ${ }^{1,2,4,28}$ After all we suggest that, in future research, beside standard anthropometric and lung function measures, dynamic hyperinflation and flow-volume curves during exercise should be measured to facilitate a better understanding of the role of increased work of breathing as possible limiting factor in the exercise capacity of patients with $\mathrm{CF}$. 
Is static hyperinflation a limiting factor during exercise in CF?

\section{Acknowledgments}

This study was funded by an unconditional research grant (DO-IT) from the Committee on Physiotherapy Research of the Royal Dutch Society for Physiotherapy (Wetenschappelijk College Fysiotherapie, Koninklijk Nederlands Genootschap voor Fysiotherapie (KNGF)). All measurements used in data analysis are part of standard routine care at the Cystic Fibrosis Center of the University Children's Hospital and Medical Center Utrecht, Utrecht, the Netherlands. 
Is static hyperinflation a limiting factor during exercise in $\mathrm{CF}$ ?

\section{References}

1. Shah AR, Gozal D, Keens TG. Determinants of aerobic and anaerobic exercise performance in cystic fibrosis. Am J Respir Crit Care Med 1998;157:1145-1150.

2. Klijn PHC, Net van der J, Kimpen JL, Helders PJM, Ent van der CK. Longitudinal determinants of peak aerobic performance in children with cystic fibrosis. Chest 2003;124(6):2215-2219.

3. Ionescu AA, Chatham K, Davies CA, Nixon LS, Enright S, Shale DJ. Inspiratory muscle function and body composition in cystic fibrosis. Am J Respir Crit Care Med 1998;158(4):1271-1276.

4. Meer de K, Gulmans VAM, Laag van der J. Peripheral muscle weakness and exercise capacity in children with cystic fibrosis. Am J Respir Crit Care Med 1999;159(3):748754.

5. Hussey J, Gormley J, Leen G, Greally P. Peripheral muscle strength in young males with cystic fibrosis. Journal of Cystic Fibrosis 2002(3);1:116-121.

6. Sahlberg ME, Svantesson U, Magnusson Thomas EML, Strandvik B. Muscular strength and function in patients with cystic fibrosis. Chest 2005;127(5):1587-1592.

7. Moser C, Tirakitsoontorn P, Nussbaum E, Newcomb R, Cooper DM. Muscle size and cardiorespiratory response to exercise in cystic fibrosis. Am J Respir Crit Care Med 2000;162(5):1823-1827. 
Is static hyperinflation a limiting factor during exercise in CF?

8. Meer de K, Jeneson JAL, Gulmans VAM, Laag van der J, Berger R. Efficiency of oxidative work performance of skeletal muscle in patients with cystic fibrosis. Thorax 1995;50(9):980-983.

9. Hjeltnes N, Stanghelle JK, Skyberg D. Pulmonary function and oxygen uptake during exercise in 16 year old boys with cystic fibrosis. Acta Paediatr Scand 1984;73(4):548553.

10. Hebestreit H, Hebestreit A, Trusen A, Hughson RL. Oxygen uptake kinetics are slowed in cystic fibrosis. Med Sci Sports Exerc 2005;37:10-17.

11. Rosenthal M, Narang I, Edwards L, Bush A. Non-invasive assessment of exercise performance in children with cystic fibrosis $(\mathrm{CF})$ and non-cystic fibrosis bronchiectasis: is there a CF specific muscle defect? Pediatr Pulmonol 2009;44(3):222-230.

12. Loring SH, Garcia-Jaques M, Malhotra A. Pulmonary characteristics in COPD and mechanisms of increased work of breathing. J Appl Physiol 2009;107(1):309-314.

13. Gibson GJ. Pulmonary hyperinflation a clinical overview. Eur Respir J 1996;9:26402649.

14. Keochkerian D, Chlif M, Delanaud S, Gauthier R, Maingourd Y, Ahmaidi S. Timing and driving components of the breathing strategy in children with cystic fibrosis during exercise. Pediatric Pulmonology 2005;40(5):449-456. 
Is static hyperinflation a limiting factor during exercise in CF?

15. Keochkerian D, Chlif M, Delanaud S, Gauthier R, Maingourd Y, Ahmaidi S. Breathing pattern adopted by children with cystic fibrosis with mild to moderate pulmonary impairment during exercise. Respiration 2008;75(2):170-177.

16. Enright S, Chatham K, Ionescu AA, Unnithan VB, Shale DJ. Inspiratory muscle training improves lung function and exercise capacity in adults with cystic fibrosis. Chest 2004;126(2):405-411.

17. Dempsey JA, Romer L, Rodmann J, Miller J, Smith C. Consequences of exerciseinduced respiratory muscle work. Respiratory Physiology \& Neurobiology 2006;151(2-3):242-250.

18. Schöni MH, Casaulta-Aebischer C. Nutrition and lung function in cystic fibrosis patients: review. Clinical Nutrition 2000;19(2):79-85.

19. Eid N, Yandell B, Howell L, Eddy M, Sheikh S. Can peak expiratory flow predict airflow obstruction in children with asthma? Pediatrics 2000;105(2):354-358.

20. Sexauer WP, Cheng H-K, Fiel SB. Utility of the breathing reserve index at the anaerobic threshold in determining ventilatory-limited exercise in adult cystic fibrosis patients. Chest 2003;124(4):1469-1475.

21. Zapletal, A., M. Samanek, and T. Paul. 1987. Lung function in children and adolescents: methods, reference values. In A. Zapletal, editor. Progress in Respiration Research. Karger, Basel. 22:114-218. 
Is static hyperinflation a limiting factor during exercise in CF?

22. de Groot JF, Takken T, de Graaff S, Gooskens RHJM, Helders PJM, Vanhees L: Treadmill testing of children who have spina bifida and are ambulatory: Does peak oxygen uptake reflect maximum oxygen uptake? Phys Ther 2009: 89: 679-687.

23. Gulmans VA, Meer K de, Binkhorst RA, Helders PJ, Saris WH. Reference values for maximum work capacity in relation to body composition in healthy Dutch children. Eur Respir J 1997;10(1):94-97.

24. Saris WHM, Noordeloos AM, Rignalda BEM, Hof van't MA, Binkhorst RA. Reference values for aerobic power of healthy 4 to 18 year old Dutch children. In: Binkhorst RA, Kemper HGC, Saris WHM, eds. Children and exercise. XI. International Series on Sport Sciences, Vol. 15. Champaign, IL, USA, Human Kinetics, 1985; pp. 151-160.

25. O’Donnell DE, Revill SM, Webb KA. Dynamic hyperinflation and exercise intolerance in chronic obstructive pulmonary disease. Am J Respir Crit Care Med 2001;164:770-777.

26. Prioux J, Matecki S, Amsallem F, Denjean A, Ramonatxo M et al. La response ventilatoire à l'exercise maximal chez l'enfant sain. Rev Mal Respir 2003;20:904-911.

27. Hart N, Polkey MI, Clément A et al. Changes in pulmonary mechanics with increasing disease severity in children and young adults with cystic fibrosis. Am J Respir Crit Care Med 2002;166(1):61-66. 
Is static hyperinflation a limiting factor during exercise in CF?

28. Lands L, Desmond KJ, Demizio D, Pavilanis A, Coates AL. The effects of nutritional status and hyperinflation on respiratory muscle strength in children and young adults. Am Rev of Respir Dis 1990;141(6):1506-1509. 
Is static hyperinflation a limiting factor during exercise in CF?

\section{Figure Captions}

Fig. 1. Associations between lung function parameters and exercise capacity. 
Female $(\mathrm{n}=50) \quad$ Male $(\mathrm{n}=69) \quad$ Total $(\mathrm{n}=119)$

\begin{tabular}{|c|c|c|c|}
\hline Age (yrs) & $13.7 \pm 1.5$ & $13.8 \pm 1.8$ & $13.8 \pm 1.7$ \\
\hline Heigth $(\mathrm{cm})$ & $156.6 \pm 7.7$ & $159.1 \pm 11.4$ & $158.1 \pm 10.1$ \\
\hline $\mathrm{BM}(\mathrm{kg})$ & $43.8 \pm 8.1$ & $44.3 \pm 10.7$ & $44.1 \pm 9.6$ \\
\hline BMI $\left(\mathrm{kg} / \mathrm{m}^{2}\right)$ & $17.8 \pm 2.1$ & $17.2 \pm 2.0$ & $17.4 \pm 2.1$ \\
\hline RV/TLC (\%) (before Ventolin) & $36.3 \pm 9.8$ & $34.4 \pm 12.8$ & $35.2 \pm 11.6$ \\
\hline RV/TLC (\%) (after Ventolin) & $33.2 \pm 9.6$ & $32.1 \pm 11.7$ & $32.5 \pm 10.9$ \\
\hline $\mathrm{FEV}_{1}$ (\% Pred.) (before Ventolin) & $80.2 \pm 19.2$ & $76.8 \pm 22.1$ & $78.2 \pm 20.9$ \\
\hline $\mathrm{FEV}_{1}$ (\%Pred.) (after Ventolin) & $84.8 \pm 20.1$ & $81.5 \pm 21.5$ & $82.9 \pm 20.9$ \\
\hline $\mathrm{HR}_{\text {rest }}($ beats/min) & $102.1 \pm 20.6$ & $100.2 \pm 14.5$ & $101.0 \pm 17.3$ \\
\hline $\mathrm{RER}_{\text {rest }}\left(\mathrm{VCO}_{2} / \mathrm{VO}_{2}\right)$ & $0.92 \pm 0.09$ & $0.91 \pm 0.08$ & $0.91 \pm 0.08$ \\
\hline $\mathrm{VO}_{2 \text { peak }}(\mathrm{L} / \mathrm{min})$ & $1.6 \pm 0.4^{\mathrm{c}}$ & $1.9 \pm 0.5$ & $1.8 \pm 0.5$ \\
\hline $\mathrm{VO}_{2 \text { peak }}(\mathrm{ml} / \mathrm{min} / \mathrm{kg})(\%$ Pred. $)$ & $\begin{array}{l}36.5 \pm 6.3^{\mathrm{a}} \\
(94.5 \pm 16.7 \%)\end{array}$ & $\begin{array}{l}44.2 \pm 8.8 \\
(94.0 \pm 19.6 \%)\end{array}$ & $\begin{array}{l}41.0 \pm 8.7 \\
(94.2 \pm 18.4 \%)\end{array}$ \\
\hline $\mathrm{W}_{\text {peak }}($ Watt $)$ & $133.3 \pm 27.4^{\mathrm{c}}$ & $152.7 \pm 48.0$ & $144.6 \pm 41.6$ \\
\hline $\mathrm{W}_{\text {peak }}($ Watt/ kg) (\%Pred.) & $\begin{array}{l}3.1 \pm 0.5^{\mathrm{a}} \\
(79.4 \pm 12.3 \%)\end{array}$ & $\begin{array}{l}3.5 \pm 0.7 \\
(76.9 \pm 16.3 \%)\end{array}$ & $\begin{array}{l}3.3 \pm 0.7 \\
(77.9 \pm 14.8 \%)\end{array}$ \\
\hline $\mathrm{HR}_{\text {peak }}($ beats/min) & $180.1 \pm 15.1$ & $179.7 \pm 19.0$ & $179.9 \pm 17.4$ \\
\hline $\mathrm{RER}_{\text {peak }}\left(\mathrm{VCO}_{2} / \mathrm{VO}_{2}\right)$ & $1.18 \pm 0.09^{b}$ & $1.13 \pm 0.08$ & $1.15 \pm 0.09$ \\
\hline $\mathrm{VE}_{\text {peak }}(\mathrm{L} / \mathrm{min})$ & $62.2 \pm 15.6^{\mathrm{d}}$ & $70.4 \pm 22.7$ & $67.0 \pm 20.3$ \\
\hline
\end{tabular}

\footnotetext{
${ }^{a}$ Significant difference between gender groups $(\mathrm{p}<0.001)$

${ }^{\mathrm{b}}$ Significant difference between gender groups $(\mathrm{p}<0.01)$

${ }^{c}$ Significant difference between gender groups $(\mathrm{p}<0.05)$ : Non parametric tested with Mann-Whitney U-test

${ }^{\mathrm{d}}$ Significant difference between gender groups $(\mathrm{p}<0.05)$

Values are presented as means $\pm \mathrm{SD}$. Abbreviations: $\mathrm{BM}=$ body mass; $\mathrm{BMI}=$ body mass index;

$\mathrm{RV} / \mathrm{TLC}=$ ratio residual volume/total lung capacity; $\mathrm{FEV}_{1}=$ forced expiration volume in one second; $\mathrm{HR}=$ heart rate; $\mathrm{RER}=$ respiratory exchange ratio $\left(\mathrm{VCO}_{2} / \mathrm{VO}_{2}\right) ; \mathrm{VO}_{2 \text { peak }}=$ peak oxygen uptake; $\mathrm{W}_{\text {peak }}=$ peak work rate; $\mathrm{VE}_{\text {peak }}=$ minute ventilation at maximal effort
} 
Table 2. Exercise capacity in static hyperinflated and non-static hyperinflated patients with CF

\begin{tabular}{lcc}
\hline & Static hyperinflation $(\mathrm{N}=65)$ & Non-static hyperinflation $(\mathrm{N}=54)$ \\
\hline $\mathrm{HR}_{\text {peak }}($ beats/min) & $176 \pm 19$ & $185 \pm 14^{\mathrm{a}}$ \\
\hline $\mathrm{RER}_{\text {peak }}\left(\mathrm{VCO}_{2} / \mathrm{VO}_{2}\right)$ & $1.14 \pm 0.09$ & $1.17 \pm 0.08$ \\
\hline $\mathrm{VE}_{\text {peak }}(\mathrm{L} / \mathrm{min})$ & $59.5 \pm 17.2$ & $76.0 \pm 20.2^{\mathrm{b}}$ \\
\hline $\mathrm{VO}_{2 \text { peak }} / \mathrm{kg}(\mathrm{ml} / \mathrm{min} / \mathrm{kg})$ & $39.2 \pm 9.2$ & $43.1 \pm 7.5^{\mathrm{b}}$ \\
\hline $\mathrm{VO}_{2 \text { peak }} / \mathrm{kg}$ Pred $(\%)$ & $91.0 \pm 20.3$ & $98.0 \pm 15.1^{\mathrm{b}}$ \\
\hline $\mathrm{W}_{\text {peak }} / \mathrm{kg}(\mathrm{Watt} / \mathrm{kg})$ & $3.1 \pm 0.7$ & $3.5 \pm 0.5^{\mathrm{b}}$ \\
\hline $\mathrm{W}_{\text {peak }} / \mathrm{kg}_{\text {Pred }}(\%)$ & $75.1 \pm 17.3$ & $81.4 \pm 10.0^{\mathrm{b}}$ \\
\hline
\end{tabular}

Values are presented as means \pm SD. Abbreviations: $H_{\text {peak }}=$ peak heart rate; $\mathrm{RER}_{\text {peak }}=$ respiratory

exchange ratio at peak exercise; $\mathrm{VE}_{\text {peak }}=$ peak minute ventilation; $\mathrm{VO}_{2 \text { peak }} / \mathrm{kg}=$ peak oxygen uptake per

kilogram body mass; $\mathrm{W}_{\text {peak }} / \mathrm{kg}=$ peak work rate per kilogram body mass; ${ }^{\mathrm{a}} \mathrm{p}<0.05$ Non parametric tested with Mann-Whitney U-test, ${ }^{\mathrm{b}} \mathrm{p}<0.05$. 
Table 3. Correlation between static hyperinflation and ventilatory limitation for different degrees of hyperinflation

\begin{tabular}{lll}
\hline & Phi coefficient & p-value \\
\hline RV/TLC $>30 \%$ & .38 & $<.001$ \\
\hline RV/TLC $>35 \%$ & .52 & $<.001$ \\
\hline RV/TLC $>40 \%$ & .50 & $<.001$ \\
\hline RV/TLC $>45 \%$ & .50 & $<.001$ \\
\hline RV/TLC $>50 \%$ & .49 & $<.001$
\end{tabular}

\footnotetext{
Values are Phi correlation coefficients with p-value. Abbreviations: RV/TLC $=$ residual volume / total lung capacity.
} 

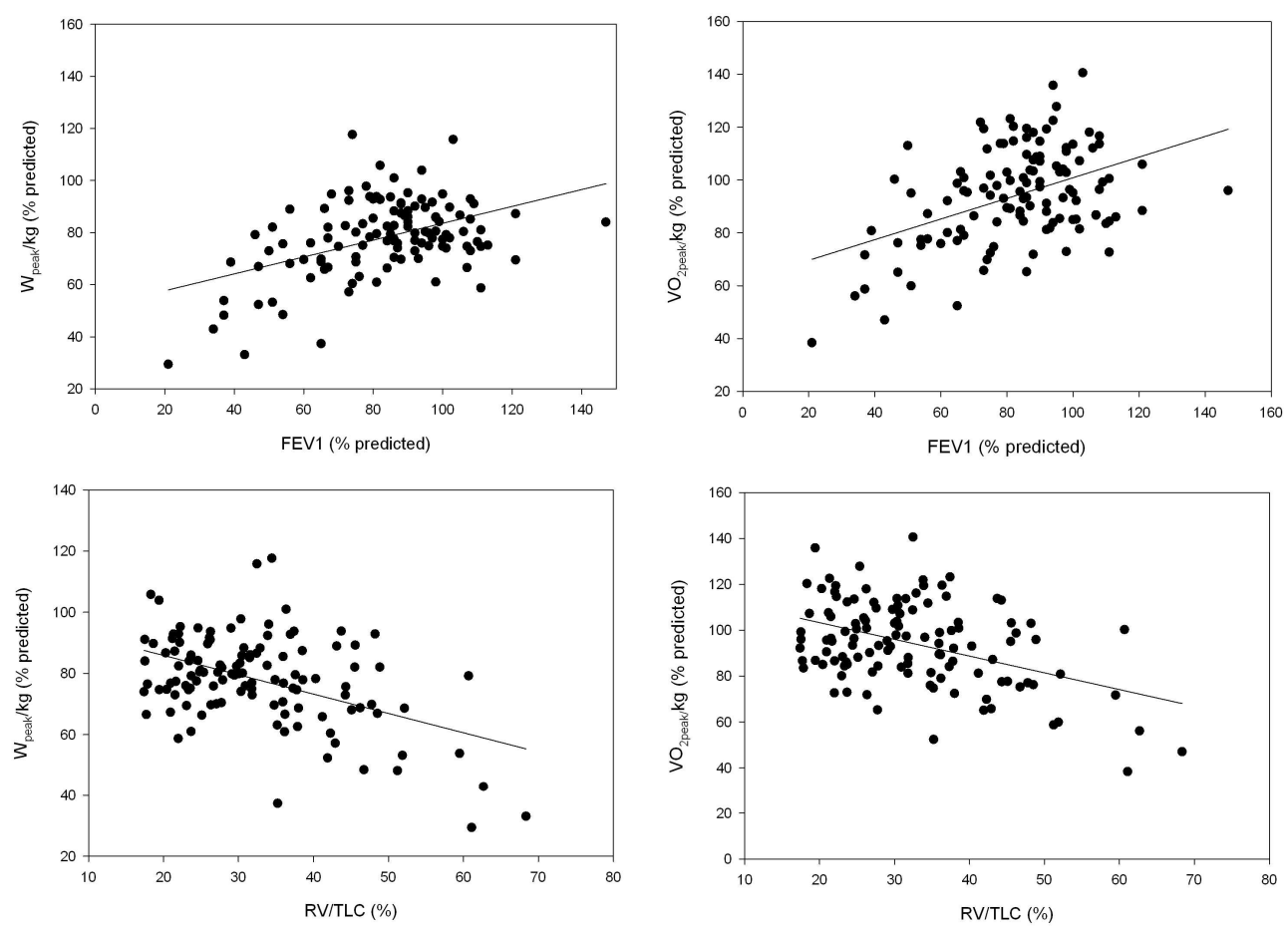

$254 \times 190 \mathrm{~mm}(300 \times 300 \mathrm{DPI})$

John Wiley \& Sons, Inc. 